\title{
The serum level of the immunomodulatory peptide cathelicidin LL37 and T helper cell type 1 inflammatory response in viral hepatitis $B, C$, and $D$
}

\author{
Nivelul seric al peptidului imunomodulator cathelicidina LL37 şi \\ răspunsul inflamator de tip celular Th 1 în hepatitele virale B,C şi D
}

\author{
Simona A. Iacob ${ }^{1 *}$, Eugenia Panaitescu ${ }^{2}$, Diana G. Iacob ${ }^{2}$, Manole Cojocaru \\ 1. The National Institute of Infectious Diseases "Matei Bals", Bucharest, Romania \\ 2. The University of Medicine and Pharmacy "Carol Davila", Bucharest, Romania \\ 3. "Titu Maiorescu” University, Bucharest, Romania
}

\begin{abstract}
Cathelicidin LL37 is an innate immunity antimicrobial peptide involved in the immune modulation of IFN- $\gamma$, the key cytokine of T helper cell type 1 (Th1) response. The role of LL37 in viral hepatitis inflammation is unknown. We assessed the serum variations of LL37 and the Th1 response in hepatitis $C$ virus (HCV), hepatitis $B$ virus $(H B V)$ and hepatitis D virus (HDV) infections. The LL37 level (Elisa detection) and Th1 response (defined by IFN- $\gamma$ level, CD4+ and CD8+ T cell count) were analyzed in 87 patients: 65 hepatitis patients $(34 \mathrm{HCV}, 18$ $H B V, 13$ HDV) and 22 healthy controls. The subjects, 33 males/ 54 women aged 20-64 years, were selected at "Matei Bals" Institut, Bucharest, Romania. Hepatitis patients were classified according to viral etiology and viral replication as active cases (detectable viremia) versus negative cases (undetectable viremia). Student $T$ test and Mann Whitney analysis were applied. High levels of LL37 (138.09 $\pm 88.45 \mathrm{ng} / \mathrm{ml}, \mathrm{p}=0.045)$ and IFN- $\gamma(69.82$ $\mathrm{pg} / \mathrm{ml}, \mathrm{p}=0.005$ ) were detected in the whole group of hepatitis. Active HCV hepatitis presented a significant increase in LL37 level (155.15 $\pm 78.84 \mathrm{ng} / \mathrm{ml}, p=0.014)$ and Thl response by comparison with inactive HCV hepatitis. Conversely active HBV patients displayed low LL37 levels $(76.75 \mathrm{ng} / \mathrm{ml}, \mathrm{p}=0.009)$ and $\mathrm{no}$ Th1 dominant response by comparison with inactive B hepatitis. High levels of LL37 up to $171.01 \pm 72.08 \mathrm{ng} / \mathrm{ml}$ and a moderate Th1 response defined HDV patients. Our results highlights increased levels of the cathelicidin LL37 in all viral hepatitis correlated with a strong and concordant immune response in active HCV hepatitis.
\end{abstract}

Keywords : Cathelicidine LL37, Th1 response, viral hepatitis

\section{Rezumat}

Cathelicidina LL37 este un peptid antimicrobian aparținând imunității înnăscute, implicat în modularea IFN- $\gamma$, citokina cheie a răspunsului T helper de tip 1. Rolul LL37 în răspunsul inflamator din cursul hepatitelor

*Corresponding author: Simona Alexandra Iacob, Ph MD, The National Institute of Infectious Diseases "Matei Bals", Popa Nan street, 61, sector 2, 24076, Bucharest, Romania Telephone number 0040724391445

E-mail: simonaaiacob@yahoo.com 
virale este necunoscut. Am evaluat variațiile serice ale LL37 şi răspunsul Th1 în infecțiile cu virus hepatitic C (HCV), cu virus hepatitis B (HBV) şi cu virus hepatitic D (HDV). Nivelul LL37 (analizat prin test ELISA) şi răspunsul Th1 (definit prin nivelul IFN- $\gamma$ şi numărul de celule CD4+ şi CD8+) au fost analizate la 87 pacienți (65 cu hepatită (34 HCV, 18 HBV, 13 HDV) şi 22 martori sănătoşi. Subiecții, 33 bărbați/54 femei, intre 20-64 ani, au fost selectați la Institutul Matei Balş, Bucureşti, România, în septembrie 2011 -martie 2012. Pacienții cu hepatită au fost analizați în funcție de etiologie şi de activitatea virală (activi vs inactivi). S-a folosit testul t student

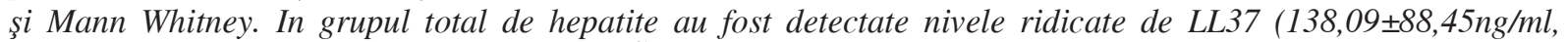

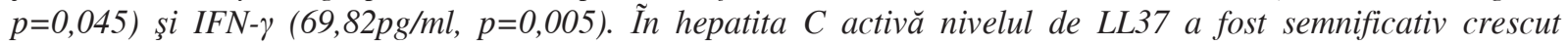
$(155,15 \pm 78,84 n g / m l, p=0,014)$ şi răspunsul Thl a fost predominant în raport cu forma inactivă. Dimpotrivă, pacienții cu hepatită B activă au prezentat LL37 scăzut (76,75ng/ml, p=0,009), fără raspuns Th1 dominant compa-

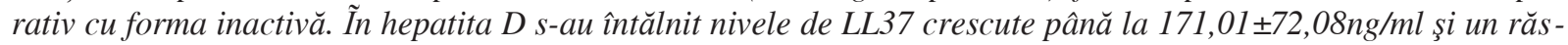
puns moderat Th1. Rezultatele indică un răspuns imun puternic şi concordant în hepatita $C$ activă şi nivele crescute de LL37 în toate hepatitele virale.

Cuvinte cheie: Cathelicidina LL37, răspuns Th1, hepatite virale

Received: 23 ${ }^{\text {rd }}$ July 2012; Accepted: $22^{\text {th }}$ February 2013; Published: $14^{\text {th }}$ March 2013.

\section{Introduction}

LL37 human cathelicidine is an antimicrobial and immunomodulatory peptide of the innate immunity released in a wide range of inflammatory diseases $(1,2)$. LL37 exhibits an immune regulatory effect involving both the innate and acquired immune response (3). Thus LL37 was reported to regulate interferon gamma (IFN$\gamma$ ), a pivotal cytokine of $\mathrm{T}$ helper cell type 1 (Th1) inflammatory response (4,5). LL37 also exhibits an immune modulating effect on myeloid dendritic cells, the innate immune key cells in orchestrating the Th1 acquired response (6) Thus depending on the exposure time and cytokine concentration, LL37 could act as either a Th1-polarized co-stimulatory molecule or as a Th1 inhibitory molecule $(7,8)$. The modulation of the immune response requires low LL37 concentrations (9) and it was previously studied in several inflammatory diseases (10). The LL37 peptide also displays a broad antimicrobial spectrum due to membrane disruption mechanisms and microbial growth inhibition. Its antibacterial activity was documented in some infections (2) including sepsis (11) and tuberculosis (12). In vitro studies also confirmed its antiviral potential (13) but the available data on the antiviral activity of LL37 against hepatitis viruses remains insufficient. Nevertheless LL37 appears to play a significant role in bile acid synthesis and its ability to bind and neutralize the heparan sulphate (14), an HCV receptor or the purinergic P2X7 receptor (15) expressed in hepatocytes $16 \mathrm{P} 2 \mathrm{X} 7$ receptor activation was documented to be critical in the outcome of the inflammatory response (17) including in HBV and HDV hepatitis (18) or autoimmune liver diseases (19). Taking into account the widespread expression of LL37 peptide in the liver epithelia as well as its antiviral and inflammatory modulating activity we hypothesized that LL37 could also take part in liver inflammatory injury induced by hepatitis viruses. The aim of our study was to assess the plasma concentration of cathelicidin LL37 peptide and Th1 inflammatory response in $\mathrm{HBV}, \mathrm{HCV}$ and HDV infections.

\section{Material and methods}

\section{Patients and samples}

The study was performed on 87 Caucasian subjects aged 20-64 years, 33 males and 54 women, HIV negative selected at "Matei Bals" National Institute of Infectious Diseases, Bucharest, Romania. Sixty five subjects were diagnosed with chronic HCV, HBV and HDV hepatitis (CDC criteria (20) and 22 were healthy controls. Samples were collected after the informed written consent has been obtained from each patient. 


\section{Laboratory analyses}

Subjects had baseline laboratory tests performed by standard hospital laboratory methods including: white blood cell count, platelets number, haemoglobin, creatinine, glycemia, alanine aminotransferease (ALT), aspartate aminotransferase (AST), alkaline phosphatase, total and ionic calcium, phosphorus, magnesium, hepatitis viral markers (Anti HCV, HbsAg, AntiHBs, HBeAg, Anti-HBe, Anti-HBc IgG/IgM, Anti-HDV), Anti-HIV. The viral load (RNA HCV, DNA HBV, RNA HDV) was detected with Real-time PCR assay (Roche Cobas TaqMan, limit of detection $45 \mathrm{UI} / \mathrm{mL}$ for RNA HCV and $55 \mathrm{UI} / \mathrm{mL}$ for DNA HBV)(21). RNA HDV was detected with TaqMan-based Real-time PCR (quantitative detection) or qualitative reverse transcription-PCR (RT-PCR assays limit of detection 20 copies $/ \mathrm{mL}$ ) at Institut für Medizinische Diagnostik Oderland, Germany. The LL-37 plasma level (expressed as $\mathrm{ng} / \mathrm{mL}$ ) was determined with the ELISA kit (HK 321 Human LL37 ELISA Kit, Hycult biotechnology, Uden, The Netherlands- detection range $0.1-100 \mathrm{ng} / \mathrm{mL}$ ). Th1 response was interpreted according to IFN$\gamma$, the CD4+, CD8+ cell count and the CD4/CD8 ratio. IFN- $\gamma$ expressed as $\mathrm{pg} / \mathrm{mL}$ was detected using ELISA kit (MaxDiscovery ${ }^{\mathrm{TM}}$ Human Interferon Gamma, Bioo Scientific, USA, assay range: $10-640 \mathrm{pg} / \mathrm{mL}$ ). CD4+ and $\mathrm{CD} 8+$ were counted with Flow cytometry. All protocols followed the manufacturer's Instructions. Each ELISA test was run in duplicate, with mean absorbance computed from the average for 2 wells normalized to a zero calibrator well. The intra-assay CV for LL37 was $<10 \%$ respectively. The inter-assays CV for LL37 was $<10 \%$.

\section{hepatitis}

\section{Classification of patients with viral}

The patients with viral hepatitis were classified according to the viral etiology ( $\mathrm{HCV}, \mathrm{HBV}$ and HDV hepatitis) and viral load (active versus inactive hepatitis). Detectable viremia suggested active hepatitis and undetectable viremia, inactive hepatitis. The following groups were analyzed:
- HCV hepatitis: 34 patients, out of which 27 with active HCV hepatitis (viral load with median values of $75000 \mathrm{UI} / \mathrm{mL}$ ) and 7 with inactive hepatitis (undetectable viremia);

- HBV hepatitis: 18 patients, out of which 12 were diagnosed with active HBV hepatitis (viral load with mean values $68000 \mathrm{UI} / \mathrm{mL}$ ) and 6 with inactive HBV hepatitis (undetectable viremia);

- HDV hepatitis: 13 patients, out of which 9 with active HDV hepatitis (detectable RNA HDV) and 4 with inactive HDV hepatitis (undetectable viremia).

\section{Statistical analysis}

Results were given as means +/-SD (standard deviation) or median. When Bartlett's test indicated that the group comparisons had equal variances Student $\mathrm{T}$ was performed. When the group data showed unequal variances, nonparametric Mann-Whitney was used. Correlations were evaluated for statistical significance with Pearson's test. A p-value $<0.05$ was considered significant. Statistical tests were performed using SPSS software (version 15).

The study was approved by "Matei Bals Institute" Hospital Scientific and Ethical Committee. The authors declare that the followed procedures were in accordance with the ethical standards of Helsinki Declaration of 1975, as revised in 2000.

\section{Results}

The mean characteristics and laboratory values of the study subjects are illustrated in Table 1 . The serum values of LL37, the Th1 response (defined by IFN- $\gamma$ serum level, CD4+ and CD8+ cells count and $\mathrm{CD} 4 / \mathrm{CD} 8$ ratio) and the respective $\mathrm{p}$ values are presented in the Table 2. Considering this data we performed a comparative analysis on the level of LL37 and Th1 response involving the following groups: a) The group of total hepatitis versus healthy controls and total active hepatitis versus inactive hepatitis; $b$ ) The groups of each viral hepatitis (HCV, HBV or HDV) versus healthy controls and 
Table 1. Mean characteristics and laboratory values in study populations

\begin{tabular}{|c|c|c|c|c|}
\hline Characteristic data & HCV patients & HBV patients & HDV patients & Healthy controls \\
\hline Number of Subjects & 34 & 18 & 13 & 22 \\
\hline Gender, male $(\%)$ & $15(44 \%)$ & $8(44 \%)$ & $5(38 \%)$ & $7(31 \%)$ \\
\hline Age, mean years (SD) & $51.32(13.88)$ & $34.13(11.54)$ & $31.90(15.92)$ & $36.22(13.86)$ \\
\hline White blood cells count $\left(\times 10^{3} / \mu \mathrm{L}\right)(\mathrm{SD})$ & $5.91(2.31)$ & $7.43(1.88)$ & $5.96(1.40)$ & $7.49(1.77)$ \\
\hline Polymorphonuclears $\left(\right.$ x $\left.10^{3} / \mu \mathrm{L}\right)(\mathrm{SD})$ & $3.25(1.28)$ & $4.93(1.87)$ & $3.51(1.11)$ & $4.54(1.69)$ \\
\hline 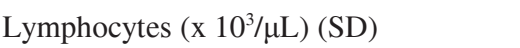 & $1.92(0.74)$ & $1.85(0.54)$ & $1.71(0.69)$ & $2.21(0.66)$ \\
\hline 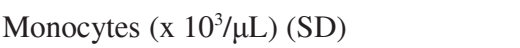 & $0.47(0.18)$ & $0.60(0.15)$ & $0.48(0.19)$ & $0.54(0.19)$ \\
\hline Blood platelet count $\left(\mathrm{x} 10^{3} / \mu \mathrm{L}\right)(\mathrm{SD})$ & $196.89(88.19)$ & $201.12(56.56)$ & $157.00(51.60)$ & $249.85(84.94)$ \\
\hline Serum ionic calcium (mg/dl) (SD) & $4.11(0.20)$ & $4.16(0.14)$ & $4.19(0.16)$ & $4.19(0.17)$ \\
\hline Serum total calcium (mg/dl) (SD) & $9.54(0.48)$ & $9.76(0.63)$ & $9.88(0.49)$ & $9.80(0.30)$ \\
\hline Serum phosphorus (mg/dl) (SD) & $3.71(0.57)$ & $3.60(0.69)$ & $4.00(0.35)$ & $3.85(0.66)$ \\
\hline Serum magnesium (mg/dl) (SD) & $1.83(0.19)$ & $1.82(0.13)$ & $1.71(0.20)$ & $1.88(0.13)$ \\
\hline Serum creatinine (mg/dl) (SD) & $0.787(0.21)$ & $0.885(0.23)$ & $0.700(0.17)$ & $0.812(0.13$ \\
\hline Serum glicemia (mg/dl) (SD) & $99.67(47.32)$ & $89.92(12.25)$ & $81.50(6.25)$ & $84.56(10.13)$ \\
\hline Serum AST, U/L (SD) & $87.44(132.8)$ & $144.4(295.2)$ & $275.5(504.0)$ & $26.95(16.2)$ \\
\hline Serum ALT, U/L (SD) & $92.24(123.9)$ & $312.0(576.3)$ & $236.1(298.3)$ & $29.14(26.1)$ \\
\hline Serum phosphatase alkaline,U/L(SD) & $88.43(53.9)$ & $113.23(105.8)$ & $106.88(49.4)$ & $104.00(98.55)$ \\
\hline Viral load (UI/mL)(median) & 75000 & 68000 & positive/ negative & \\
\hline
\end{tabular}

$\mathrm{HCV}$ : hepatitis C virus; $\mathrm{HBV}$ : hepatitis B virus, HDV: hepatitis D virus, AST: aspartate aminotransferase; ALT: alanine aminotransferase

each group of active HCV, HBV or HDV hepatitis versus the corresponding inactive forms.

\section{a. Comparative analysis of LL37} status and Th1 response in total hepatitis versus healthy controls and total active hepatitis versus inactive forms

The status of LL37 and Th1 response for the stated groups is represented in the Figure 1. Significant high values of LL37 and IFN- $\gamma$ were found in hepatitis patients versus healthy controls ( $\mathrm{p}=0.045$ and $\mathrm{p}=0.005$ respectively). The group of active hepatitis presented a dominant Th1 response (increased IFN- $\gamma$, CD4+ and CD8+ cell count) compared to inactive hepatitis but the only statistical difference applied to the $\mathrm{CD} 4+$ cell count $(\mathrm{p}=0.023)$.

b. Comparative analysis of LL37 status and Th1 response in each group of $\mathrm{HCV}, \mathrm{HBV}$, and HDV hepatitis versus healthy controls and active versus inactive forms

The status of LL37 and Th1 response for the stated groups is represented in the Figure 2.
The level of LL37 was increased in all hepatitis groups (HCV, HBV, HDV) compared to healthy controls with significance for the $\mathrm{HCV}$ group $(\mathrm{p}=0.0464)$. Moreover HCV patients presented increased levels of IFN- $\gamma(\mathrm{p}=0.0001)$ consistent with the significant raise of LL37. A considerable increase in LL37 level was recorded in the active group of HCV hepatitis $(\mathrm{p}=0.014)$ accompanied by an increased IFN- $\gamma(\mathrm{p}=0.019), \mathrm{CD} 4+$ cell count $(p=0.004)$ and CD8+ cell count (0.067). Consequently the active $\mathrm{HCV}$ hepatitis group presented a well defined immune profile, involving an increased serum concentration of LL37 and a dominant Th1 response. On the other hand, analysis of HBV infected patients disclosed significant increases of LL37 level in inactive forms only $(\mathrm{p}=0.009)$ lacking a significant Th1 response. HDV infected inactive patients displayed increased serum levels of LL37 without statistically significant results by comparison with active HDV hepatitis $(\mathrm{p}=0.377)$. 
Table 2. Serum values of LL37 and Th1 response (IFN- $\gamma$ serum level, CD4, CD8 cell count and CD4/CD8 ratio) in viral hepatitis versus controls and active versus inactive hepatitis

\begin{tabular}{|c|c|c|c|c|c|}
\hline $\begin{array}{l}\text { The group of } \\
\text { patients }\end{array}$ & $\begin{array}{c}\text { LL37 serum } \\
\text { level }(\mathrm{ng} / \mathrm{ml}) \pm \mathrm{SD}\end{array}$ & $\begin{array}{l}\text { IFN- } \gamma \text { serum } \\
\text { level }(\mathrm{pg} / \mathrm{ml})\end{array}$ & $\begin{array}{c}\text { CD4 cell } \\
\text { count } / \mathrm{mm}^{3} \pm \mathrm{SD}\end{array}$ & $\begin{array}{c}\text { CD8 cell } \\
\text { count } / \mathrm{mm}^{3} \pm \mathrm{SD}\end{array}$ & $\begin{array}{l}\mathrm{CD} 4 / \mathrm{CD8} \\
\text { ratio } \pm \mathrm{SD}\end{array}$ \\
\hline \multicolumn{6}{|l|}{ Total hepatitis } \\
\hline Total hepatitis & $138.09 \pm 88.45$ & 69.82 & $793.47 \pm 307.7$ & $482.58 \pm 257.8$ & $1.97 \pm 0.96$ \\
\hline Controls & $97.55 \pm 60.11$ & 14.48 & $881.50 \pm 258.9$ & $567.53 \pm 207.4$ & $1.80 \pm 0.83$ \\
\hline$P$-value & $0.045 *$ & $0.005 * *$ & $0.334 *$ & $0.285 *$ & $0.580 *$ \\
\hline Active hepatitis & $133.27 \pm 77.72$ & 77.23 & $860.54 \pm 308.4$ & $509.71 \pm 243.2$ & 1.80 \\
\hline Inactive hepatitis & $151.43 \pm 114.40$ & 58.70 & $645.93 \pm 258.0$ & $424.15 \pm 288.2$ & 1.44 \\
\hline$P$-value & $0.472 *$ & $0.323 * *$ & $0.023 *$ & $0.329 *$ & $0.40^{* *}$ \\
\hline \multicolumn{6}{|l|}{ HCV hepatitis } \\
\hline HCV patients & $137.92 \pm 80.01$ & 91.83 & $786.12 \pm 311.29$ & $426.18 \pm 224.64$ & $2.26 \pm 1.13$ \\
\hline Controls & $97.55 \pm 61.13$ & 14.48 & $881.50 \pm 258.96$ & $567.53 \pm 207.46$ & $1.80 \pm 0.83$ \\
\hline$P$-value & $0.0464 *$ & $0.0001 * *$ & $0.3374^{*}$ & $0.0735^{*}$ & $0.2151 *$ \\
\hline Active HCV & $155.15 \pm 78.84$ & 164.81 & 923 & $479.56 \pm 212.2$ & 2 \\
\hline Inactive HCV & $73.92 \pm 46.67$ & 19.07 & 465.5 & $283.83 \pm 208.2$ & 1.96 \\
\hline$P$-value & $0.014 *$ & $0.019 * *$ & $0.004 * *$ & $0.067 *$ & $0.82 * *$ \\
\hline \multicolumn{6}{|l|}{ HBV hepatitis } \\
\hline HBV patients & 108.49 & 41.57 & $849.71 \pm 341.20$ & $543.20 \pm 215.80$ & $1.56 \pm 0.46$ \\
\hline Controls & 72.32 & 14.48 & $881.50 \pm 258.96$ & $567.53 \pm 207.46$ & $1.80 \pm 0.83$ \\
\hline$P$-value & $0.0877 * *$ & $0.1719 * *$ & $0.7835^{*}$ & $0.7867 *$ & $0.4219 *$ \\
\hline Active HBV & 76.75 & 24.57 & $866.88 \pm 352.03$ & $539.85 \pm 176.31$ & $1.64 \pm 0.41$ \\
\hline Inactive HBV & 174.66 & 70.23 & $818.80 \pm 358.66$ & $551 \pm 340.85$ & $1.37 \pm 0.62$ \\
\hline$P$-value & $0.009 * *$ & $0.133 * *$ & $0.811 *$ & $0.945^{*}$ & $0.439 *$ \\
\hline \multicolumn{6}{|l|}{ HDV hepatits } \\
\hline HDV patients & $136.94 \pm 88.41$ & 29.40 & $726.44 \pm 256.71$ & $553.11 \pm 358.73$ & $1.71 \pm 0.75$ \\
\hline Controls & $97.55 \pm 61.13$ & 14.48 & $881.50 \pm 258.96$ & $567.53 \pm 207.46$ & $1.80 \pm 0.83$ \\
\hline$P$-value & $0.1239 *$ & $0.8562 * *$ & $0.1743 *$ & $0.9059 *$ & $0.7984 *$ \\
\hline Active HDV & $121.79 \pm 94.53$ & 48.89 & $785 \pm 326.11$ & $564 \pm 418.32$ & $1.87 \pm 0.847$ \\
\hline Inactive HDV & $171.01 \pm 72.08$ & 43.83 & $653.25 \pm 145.16$ & $539.50 \pm 330.77$ & $1.51 \pm 0.68$ \\
\hline$P$-value & $0.377 *$ & $0.880 *$ & $0.481 *$ & $0.926^{*}$ & $0.509 *$ \\
\hline
\end{tabular}

Values are expressed as mean \pm SD (standard deviation) or median; * T Student, ** Mann Whitney test.

\section{Discussion}

Hepatitis infections with HBV, HCV and HDV viruses are some of the most common inflammatory disorders in the world and leading causes of cirrhosis and hepatocellular carcinoma. The mechanisms behind viral persistence and liver inflammatory damage are still obscure. Clinical trials and chimpanzee experiments suggested that the final outcome in viral hepatitis directly depends on the efficient cooperation between the innate and acquired immune response (22) .The innate immune response hinders viral replication in the early stages of hepatitis infection employing NK cells, dendritic cells and also cytokines such as IFN- $\gamma$ and IFN- $\alpha$. Nevertheless a subsequent strong and multispecific Th1 response is required for the clearance of hepatitis viruses $(23,24)$. The absence of a sustained Th1 re- 

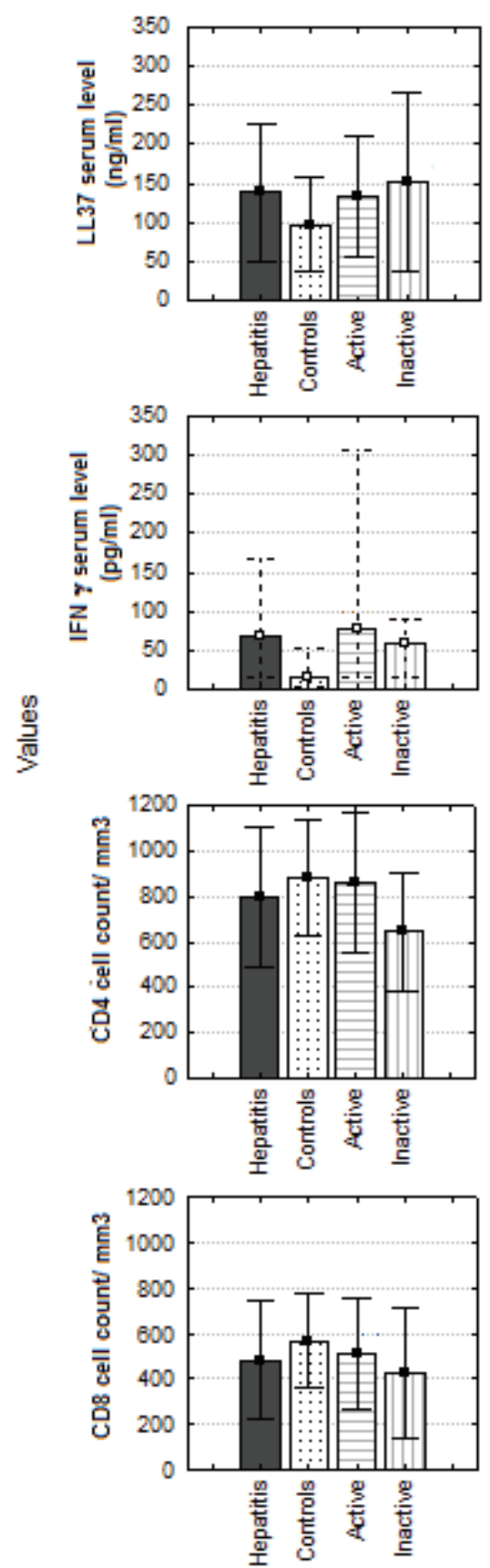

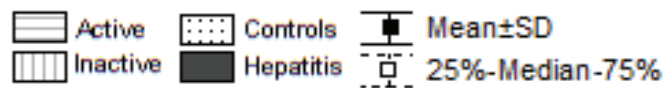

Figure 1. Comparative status of LL37 and Th1 response (IFN- $\gamma, \mathrm{CD} 4+$ and $\mathrm{CD8}+$ serum level) in total hepatitis group versus controls and active versus inactive patients. sponse facilitates the viral persistence while an uncontrolled Th1-mediated inflammation accounts for ongoing liver damage and fibrogenesis (25). The intrahepatic recruitment of Th1 inflammatory cells is ensured by IFN- $\gamma$, a hallmark cytokine of both the innate and acquired immune response (26). Hepatitis viruses were documented to inhibit the release of IFN- $\gamma$, thus repressing the Th1 response (27). LL37, a molecule of innate immunity regulated by vitamin $\mathrm{D}$ activity, exhibits in vitro an immune modulating effect on IFN- $\gamma$ and also on Th1 acquired response (6) A high level of LL37 seems to balance an adequate inflammatory response.The enhanced activity of LL37 was particularly studied in inflammatory dermatoses. The therapeutic possibilities of LL37 were also addressed in organ transplant recipients as well as in pulmonary, urinary, intestinal or systemic infections $(11,14,28)$. No data is currently available regarding the serum level and the immunomodulating activity of LL37 in viral hepatitis. Nevertheless the LL37 immunomodulatory role and its antiviral activity observed in vitro, raise the possibility of LL37 interfering with the inflammatory injury induced in viral hepatitis infections. The aim of our study was to observe the serum level of this peptide and Th1 inflammatory response in viral $\mathrm{B}, \mathrm{C}$ and $\mathrm{D}$ hepatitis.

The study revealed the following:

-The serum level of LL37 was significantly increased in all patients with viral hepatitis $(138.09 \mathrm{ng} / \mathrm{mL})$ compared to controls $(97.55$ $\mathrm{ng} / \mathrm{mL})(\mathrm{p}=0.04)$. Regarding the active and inactive hepatitis groups, LL37 was significantly raised in active HCV (151.43 ng/mL, p=0.014) and inactive HBV hepatitis (174.66 ng/mL, $\mathrm{p}=0.009$ ). The current study revealed a lower LL37 serum concentration compared to levels previously reported in bacterial infections $(29,30)$ but significantly higher than serum values observed in tuberculosis $(49.5 \mathrm{ng} / \mathrm{mL})(31)$. The intense chemotactic activity of LL37 (5) could also trigger the local accumulation of immune cells, releasing new amounts of LL37. 

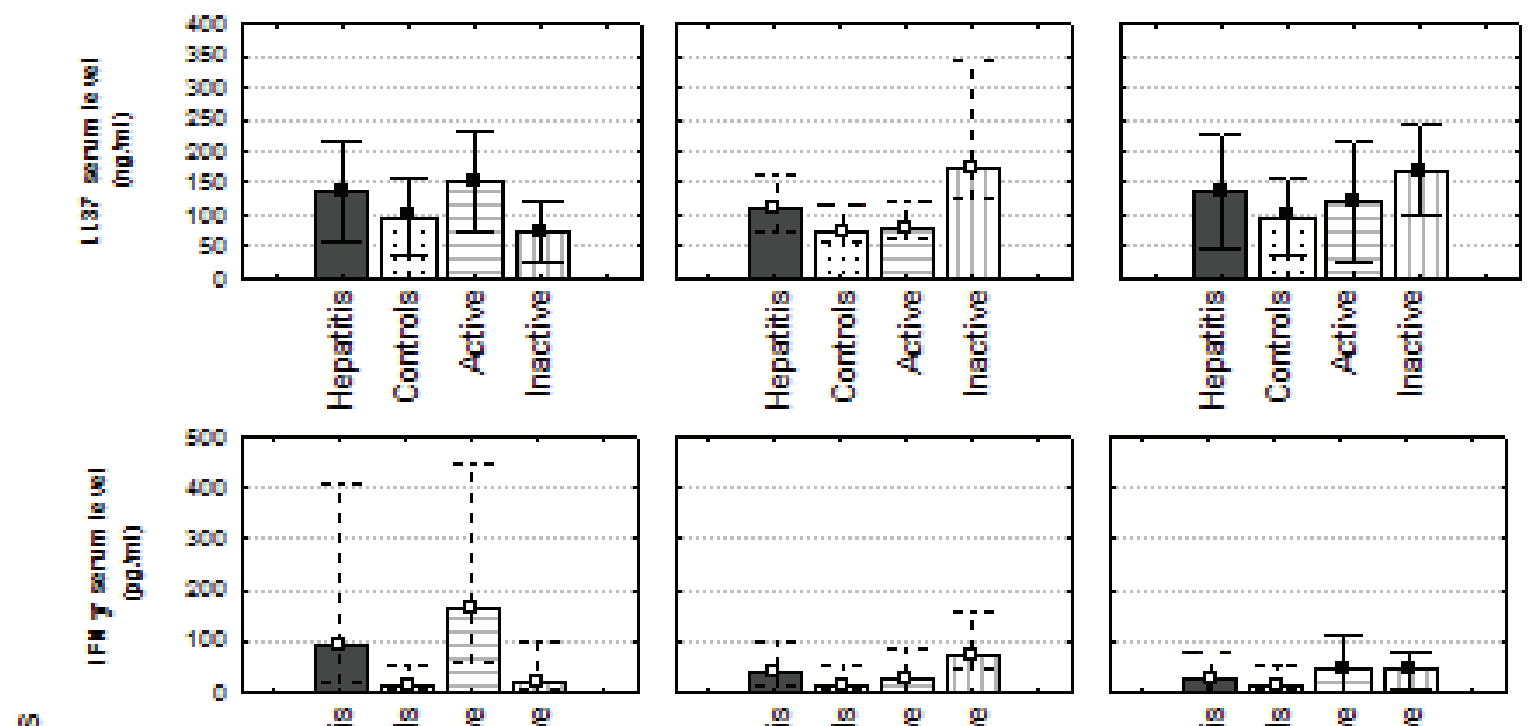

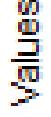

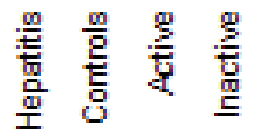

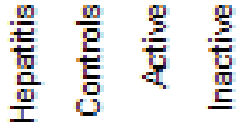

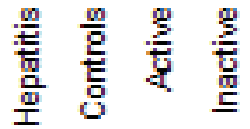

总
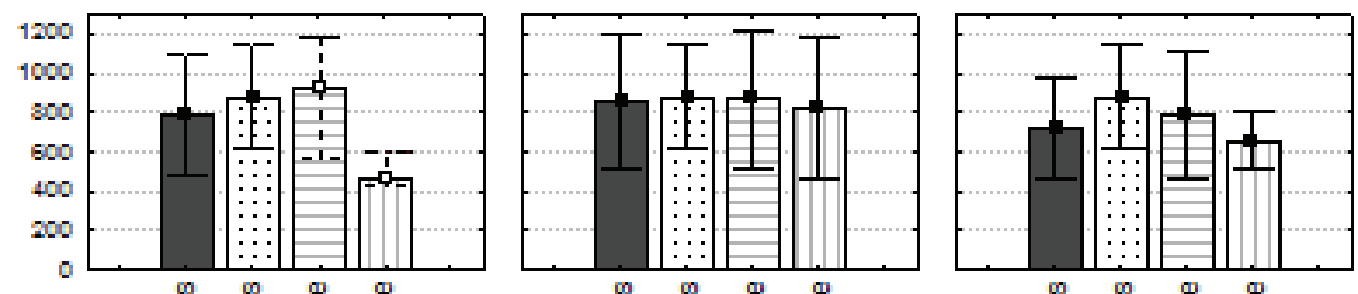

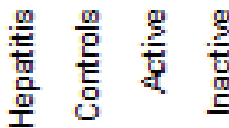

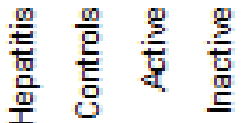

总望
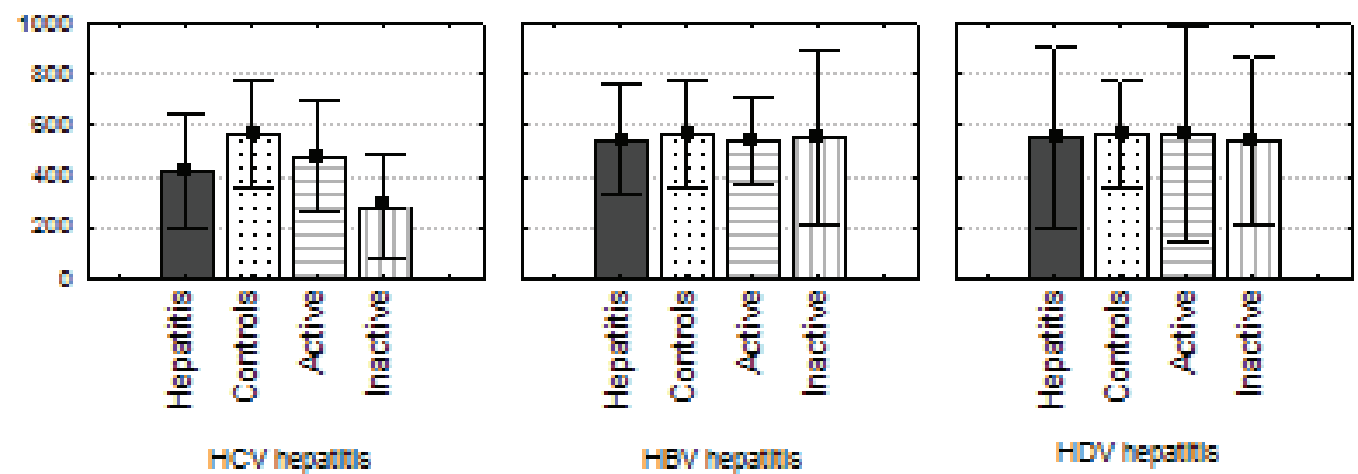

HBV hepatitis

HDV hegatitls

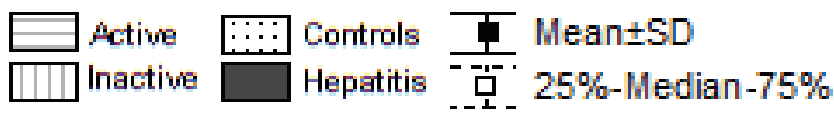

Figure 2. Comparative status of LL37 and Th1 response (IFN- $\gamma$, CD4+ and CD8+ level) in each HCV, HBV, HDV hepatitis group versus controls and each active versus inactive forms. 
Therefore it is possible that the hepatic concentration of LL37 exceeds the serum level. The variations of LL37 in active HCV and inactive HBV hepatitis were consistent with those of IFN- $\gamma$. However the correlation between the plasma IFN- $\gamma$ and LL37 levels was weak $(\mathrm{R}=0.257$, Pearson correlation, data not shown.). A larger patient cohort is required to estimate the correlation between these molecules. Anyway a divergent inflammatory response was observed in $\mathrm{B}$ and $\mathrm{C}$ hepatitis as to the viral replication status.

- The Th1 immune response revealed a dominant pattern in HCV active hepatitis compared to inactive hepatitis. Thus HCV active hepatitis patients recorded significantly increased values of IFN- $\gamma(164.81 \mathrm{pg} / \mathrm{mL}, \mathrm{p}=0.019), \mathrm{CD} 4+$ cell count $(923$ cells $/ \mathrm{mm} 3, \mathrm{p}=0.004)$ and $\mathrm{CD} 8+$ cell count (479 cells $/ \mathrm{mm} 3, \mathrm{p}=0.067$ ). Interestingly if we consider the group of total hepatitis by comparison with healthy controls, the IFN- $\gamma$ level was increased while both CD4+ and CD8+ T cell count were decreased. This could be the result of IFN- $\gamma$ production mainly by cells of the Innate Immune response instead of CD4+ or CD8+ lymphocytes. If this is correct, the Innate Immune response could be of considerable importance during viral replication in chronic hepatitis infections (primarily concerning $\mathrm{HCV}$ infections), releasing high levels of IFN- $\gamma$ and immunomodulatory peptides such as LL37. In previous studies we have studied the level of LL37 in the HCV infection in correlation with the necroinflammatory liver activity or viral replication (32).Results have indicated a higher level of LL37 in C hepatitis with moderate necroinflammatory activity (Fibromax A score below 2) as well as an increased level of LL37 in replicative $\mathrm{HCV}$ infections. At the same time no positive correlation was found in one study between the level of LL37 and the concentration of 25-hydroxy vitamin D (32). Moreover the concentration of 25-hydroxy vitamin D in patients with HCV replicative infection was modestly correlated with hepatic inflammation but strongly cor- related with the CD4+ $\mathrm{T}$ cell count and ionic calcium. In this previous studies the Th1 inflammatory response was only partially assessed -following the CD4 response- and only in correlation with 25-hydroxy vitamin D level. The purpose of the present study was an extensive analyses of Th1 inflammatory response (defined by the plasma level of IFN- $\gamma, \mathrm{CD} 4, \mathrm{CD} 8$ cells) and the LL37 peptide. Moreover the analysis was performed on HCV as well as on HBV and HDV infection. The patients with HCV replicative infection exhibited a strong correlation between LL37 and the Th1 inflammatory response. The role of LL37 appeared to be of considerable importance in the immune response against the $\mathrm{HCV}$ infection by comparison with vitamin D. As consequences the treatment with vitamin D as an immunomodulator in chronic hepatitis should be carefully weighed against the impact of induced LL37 on the inflammatory response. Thus an excessive concentration of LL37 could over- stimulate the Th1 response and the subsequent necrosis of hepatocytes in the HCV replicative infection. On the other hand the synthesis of LL37 retains a protective role in the HBV and HDV infection.

There are several limits of our investigation. Firstly the study was performed on a low number of patients, especially in what regards patients with HDV hepatitis. A larger group of patients could have had a more significant influence on the presented data. Secondly, our analysis was based on the serum level of LL37 and immune markers which are mostly connected to the systemic and not intrahepatic inflammatory response. The hepatic inflammatory reaction could be significant but difficult to assess.

However the immune response in viral hepatitis is only partially defined. The role of the innate immunity has been less studied and is hard to asses in vivo. In vitro studies of LL37 and hepatitis viruses (both human specific) are impeded by the lack of adequate cellular models. Moreover in vitro studies are unable to explore the dynamics of the immune response. 
Our study has the advantage to investigate the correlation between LL37 and the Th1 response in patients with different viral hepatitis and different viral replication status.

Further studies on larger patient groups are required in order to asses the importance of the innate immune peptide LL37 in modulating Th1 cellular response in the viral hepatitis.

\section{Conclusion}

The increased serum levels of LL37 found in $\mathrm{B}, \mathrm{C}$, and $\mathrm{D}$ hepatitis suggest the importance of this innate immunity peptide in viral hepatitis. The Th1 response and LL37 level were concordant in active HCV hepatitis but diverged in other types of viral hepatitis. Further studies are needed to fully understand the active role of cathelicidin LL37 in viral hepatitis and its possible therapeutical implications.

\section{Acknowledgements}

This study was supported in full by The National Romanian Council of the Higher Education's Scientific Research (CNCSIS) (grant number 2008 ID 2508).

No conflict of interest to declare

\section{Abbreviations}

ALT =alanine aminotransferease

$\mathrm{AST}=$ aspartate aminotransferase

$\mathrm{HCV}=$ hepatitis $\mathrm{C}$ virus

$\mathrm{HBV}=$ hepatitis $\mathrm{B}$ virus

$\mathrm{HDV}=$ hepatitis D virus

Th1 $=$ T helper cell type 1 response

IFN- $\gamma=$ interferon gamma

\section{References}

1. Zanetti M, Gennaro R, Romeo D. Cathelicidins: a novel protein family with a common proregion and a variable C-terminal antimicrobial domain. FEBS Lett. 1995; 374: $1-5$.

2. Nizet V, Gallo RL. Cathelicidins and innate defense against invasive bacterial infection. Scand J Infect Dis 2003; 35: 670-676.
3. Scott MG, Davidson DJ, Gold MR, Bowdish D, Hancock RE. The human antimicrobial peptide LL-37 is a multifunctional modulator of innate immune responses. J Immunol. 2002; 169:3883-3891.

4. Nijnik A, Pistolic J, Wyatt A, Tam S, Hancock R. Human Cathelicidin Peptide LL-37 Modulates the Effects of IFN- $\gamma$ on APCs. The Journal of Immunology 2009; 183 (9) $5788-5798$.

5. Agerberth B, Charo J, Werr J, Olsson B, Idali F, Lindbom $\mathrm{L}$, The human antimicrobial and chemotactic peptides LL-37 are expressed by specific lymphocyte and monocyte populations. Blood 2000; 96 (9): 3086-3093.

6. Davidson DJ. The cationic antimicrobial peptide LL37 modulates dendritic cell differentiation. J Immunol 2004; 172(2):1146-1156.

7. Bucki R, Leszczynska K, Namiot A, Sokolowski W. Cathelicidin LL37: a multitask antimicrobial peptide. Arch Immunol Ther Exp 2010; 58:15-25.

8. Kandler K, Shaykhiev R, Kleemann P,Klesca F, Lohoff M, Vogelmeier . C The anti-microbial peptide LL-37 inhibits the activation of dendritic cells by TLR ligands, Int. Immunol. (2006) 18 (12): 1729-1736

9. Mookherjee N, Brown KL, Bowdish D, Doria S, Falsafi R, Hokamp K et al. Modulation of the TLR-mediated inflammatory response by the endogenous human host defense peptide LL-37. The Journal of Immunology 2006; 176: 2455-2464.

10. Doss M, White M, Tecle T, Hartshorn KL, Human defensins and LL-37 in mucosal immunity, Journal of Leukocyte Biology 2010; 87 (1);79-92

11. Golec M. Cathelicidin LL-37: LPS-neutralizing, pleiotropic peptide. Ann Agric Environ Med 2007; 14(1):1-4.

12. Rivas-Santiago B, Hernandez-Pando R, Carranza C. Expression of cathelicidin LL-37 during Mycobacterium tuberculosis infection in human alveolar macrophages, monocytes, neutrophils, and epithelial cells. Infection and Immunity 2008; 76 (3): 935-941

13. Cole AM, Lehrer RI. Minidefensins and other antimicrobial peptides: candidate anti-HIV microbicides. Expert Opin Ther Targets 2003; 7:329-341. doi: 10.1517/eott.7.3.329.22436

14. Andersson E, Rydengård V, Sonesson A, Mörgelin M, Björck L, Schmidtchen A. Antimicrobial activities of heparin-binding peptides, 2004, European Journal of Biochemistry 271 (6);1219-1226

15. Taylor JM, Han Z. Purinergic Receptor Functionality Is Necessary for Infection of Human Hepatocytes by Hepatitis Delta Virus and Hepatitis B Virus, PLoS One. 2010; 5(12): e15784.doi: 10.1371/journal.pone.0015784

16. Barth H, Schnober EK, Zhang F, Linhardt RJ, Depla $\mathrm{E}$, Boson B et al. Viral and cellular determinants of the hepatitis $\mathrm{C}$ virus envelope-heparan sulfate interaction. Journal of Virology 2006; 80 (21): 10579-10590.

17. Kaneider NK, Djanani A, Wiedermann CJ. Heparan sulfate proteoglycan-involving immunomodulation by 
cathelicidin antimicrobial peptides and PR39". The Scientific World Journal 2007; 7:1832-1838.

18. Agnello V, Abel G, Elfahal M, Knight GB, Zhang QX. Hepatitis $C$ virus and other flaviviridae viruses enter cells via low density lipoprotein receptor. Proc Natl Acad Sci USA 1999; 96(22):12766-12771.

19. Sørensen O, Bratt T, Anders H, Madsen MT, Borregaard $\mathrm{N}$. The human antibacterial cathelicidin, hCAP18 , is bound to lipoproteins in plasma, The Journal of Biological Chemistry 1999; 274(32): 22445-22451

20. Guidelines For Viral Hepatitis Surveillance And Case Management, 2009 http://www.cdc.gov/hepatitis/SurveillanceGuidelines.htm). 21. Laborator Synevo.Ghidul serviciilor medicale. Referinte specifice tehnologiei de lucru utilizate editia. Catalog 2007-2008: 555-562 http://www.synevo.com.ro

22. Nascimbeni M, Mizukoshi E, Bosmann M, Major ME, Mihalik K, Rice CM et al. Kinetics of CD4+ and $\mathrm{CD} 8+$ memory $\mathrm{T}$-cell responses during hepatitis $\mathrm{C}$ virus rechallenge of previously recovered chimpanzees. Journal of Virology 2003; 77 (8): 4781-4793.

23. Eckels DD, Wang H, Bian TH, Tabatabai N, Gill JC. Immunobiology of hepatitis $\mathrm{C}$ virus (HCV) infection: the role of CD4 T cells in HCV infection. Immunol Rev 2000; 174: 90-97.

24. Yang PL, Althage A, Chung J, Maier H, Wieland S, Isogawa $\mathrm{M}$ et al. Immune effectors required for hepatitis B virus clearance. PNAS 2010; 107 (2): 798-802.

25. Napoli J, Bishop GA, McGuinness PH, Painter DM, McCaughan GW. Progressive liver injury in chronic hepatitis $\mathrm{C}$ infection correlates with increased intrahepatic expression of Th1-associated cytokines. Hepatology 1996;
24: 759-765.

26. Frese M, Schwarzle V, Barth $\mathrm{K}$ et al. Interferon-gamma inhibits replication of subgenomic and genomic hepatitis C virus RNAs. Hepatology 2002; 35: 694-703 27. Kondo Y, Sung VM, Machida K, Liu M, Lai MM. Hepatitis $\mathrm{C}$ virus infects $\mathrm{T}$ cells and affects interferon-gamma signaling in $\mathrm{T}$ cell lines. Virology 2007; 361(1): 161-173.

28. Tjabringa GS, Rabe K, Hiemstra P. The human cathelicidin LL-37: a multifunctional peptide involved in infection and inflammation in the lung Pulmonary Pharmacology \& Therapeutics 2009; 18 (5); 321-327.

29. Sørensen, O, Cowland JB, Askaa J, Borregaard N. An ELISA for hCAP-18, the cathelicidin present in human neutrophils and plasma. J. Immunol Methods 1997; 206: 53-59.

30. Gombart AF, Bhan I, Borregaard N, Tamez H, Camargo CA Jr, Koeffler HP et al. Low plasma level of cathelicidin antimicrobial peptide (hCAP18) predicts increased infectious disease mortality in patients undergoing hemodialysis. Clin Infect Dis 2009; 48(4):418-424.

31. Yamschchikov AV, Kurbatova EV, Kumari M, Blumberg HM, Ziegler TR, Ray SM et al. Vitamin D status and antimicrobial peptide cathelicidin (LL-37) concentrations in patients with active pulmonary tuberculosis. Am J Clin Nutr September 2010; 92 (3) 603-611.

32. Iacob SA, Panaitescu E, Iacob DG, Cojocaru M. The human cathelicidin LL37 peptide has high plasma levels in $\mathrm{B}$ and $\mathrm{C}$ hepatitis related to viral activity but not to 25-hydroxyvitamin D plasma level. Rom J Intern Med 2012;50(3):217-23. 